\title{
The Threats to the World Trading System
}

\author{
Jagdish Bhagwati
}

\section{INTRODUCTION}

$\mathfrak{I}$ intend to consider here the prospects for the GATT-focused multilateral trading system, the perils it faces and the promise it nonetheless holds. The threats faced at present by the GATT arise from a variety of factors, including changes in the world economy. These changes have produced fissiparous tendencies gnawing at many of the basic principles embodied in the GATT.

Recalling the preamble to the GATT, and mindful of its central articles, the following may justifiably be cited as the main principles of the GATT:

- A 'fix-rule' trading regime is to be preferred to a 'fix-quantity' one. In other words, 'managed trade' (or 'results-oriented' trade), which seeks quantitative targets of outcomes in trade instead of settling on rules and letting chips fall where they may, is to be rejected.

- Multilateralism, where these trade rules extend without discrimination to all members of the trading regime, is generally to be preferred to discriminatory arrangements.

- Markets are to be opened through conventional reduction in trade barriers, and new disciplines are to be established, by resort to mutuality and balance of concessions, ruling out aggressive, unilaterally-determined demands for unrequited concessions that could come from the strong against the weak.'

- And in the same spirit of the rule of law, the adjudication of dispute must be impartial, pitting the strong against the weak in equal contest, both the balance

JAGDISH BHAGWATI is Arthur Lehman Professor of Economics and Professor of Political Science at Columbia University, New York. This article is based primarily on, while extending somewhat (principally in the section on Regionalism) the ideas in the Seventh Harry G. Johnson Memorial Lecture, delivered at the Royal Society of Arts in London on $11 \mathrm{July}, 1990$, and now published as The World Trading System at Risk (1991b). The views expressed are personal and do not reflect those of the GATT where the author is Economic Policy Adviser to the Director General.

${ }^{1}$ In turn, this would tend to undercut multilateralism as the strong move to get preferential concessions for themselves and the weak grant them at the expense of the trade with the not-sostrong. 
of negotiations and the impartiality of dispute settlement reflecting the correct and growing perception that the GATT system provides the best defence of the weak.

I consider here the serious challenges to these GATT principles of multilateralism that have recently arisen from several directions and taken the form of an advocacy of managed trade, aggressive unilateralism and regionalism. Underlying these phenomena, though deriving strength also from other factors, is a common thread: the increasing sensitivity to 'unfair trade' and the sense that the methods of the GATT-based multilateral trading system cannot cope with the issues that alleged unfair trade by one's rivals forces on our attention. ${ }^{2}$

\section{THE GATT ARCHITECTURE: THE THREAT}

\section{a. The Rise of Unfair Trade}

At the outset, it should be noted that there is a strong case for free trade to be complemented by fair trade. One can argue that a free trade regime (such as the GATT), overseeing trade among trading nations, must embody the principle of largely symmetric free trade by each; otherwise, the efficient allocation of activity among trading nations that the regime must reflect will be compromised by the licence taken by those who stray.

There is also the prudential argument that, even if one were not interested in cosmopolitanism and were actuated only by considerations of narrow national interest, one's own ability to sustain free trade would be imperilled in practice if one's rivals were considered to be trading unfairly. Pluralism politics will generally rule out accommodation to free trade unless trade is also seen to be fair.

Hence, the liberalisation of trade has always been accompanied by the institution or activation of the two now-conventional measures against unfair trade: countervailing duty (CVD) against foreign subsidisation of exports and the antidumping $(\mathrm{AD})$ duty to counteract the presumably predatory effects of dumping.

The problem is that 'unfair trade' is a two-face creature; one face is friendly to free trade; the other frowns on it. Measures against unfair trade can be misused to allege unfair trade unfairly and thus to undermine free trade. And new definitions of widening scope, of what constitutes unfair, 'unreasonable' and unacceptable trade can be invented in unending improvisations. It is this other, ugly face that we currently see and must fear. Why? There are several reasons.

1. Perhaps the most compelling reason for the increase in allegations of unfair trade is simply the outbreak of protectionist pressures in the early 1980s, combined with the fact that protection is easier to procure if the successful foreign rival is alleged to be unfairly trading than if one pleads for it merely by citing the difficulty to one's situation.

\footnotetext{
${ }^{2}$ I have dealt with these concerns and their consequences at much greater length, comparing them also with earlier market-failure-related threats to the world trading system, in Bhagwati (1991a).
} 
2. Again, the implausibility with which such allegations can be made by protectionists is diminished by the increased focus on non-tariff barriers (NTBs) relative to now-negligible tariffs. The latter are transparent and indeed, uncomplicated. Gertrude Stein could have said, 'A tariff is a tariff is a tariff.' But NTBs are hard to handle. Suspicions often linger of their invisible hand strangulating trade.

3. In addition, there are changes in the world economy that reinforce the rise of unfair-trade concerns to centre stage. Three merit attention. Perhaps the most important factor, responsible in particular for the American conversion to neurosis on this front, has been the relative decline of the United States in the world economy, leading to what was referred to in Bhagwati and Irwin (1987) as the Diminished Giant Syndrome.

The Diminished Giant Syndrome of the United States now parallels Britain's at the end of the 19th century when the United States and Germany arrived on the world scene. But the trade panic and the attendant petulance about the rivals have an extra edge in the United States today. The psychological need to be 'number one' is evidently more compelling in a country where there is ceaseless ranking of institutions, corporations, the sartorially elegant and the wealthiest. And then again, the country whose rise promotes the challenge, Japan, is one that is peculiarly susceptible to charges of unfair trade. Indeed, such allegations against Japan have been so common for at least half a century that today's Japan-bashers, in reviving old and fearful stereotypes about Japan, should be called regressionists' rather than the 'revisionists' they fancy themselves to be.

4. The change in the world economy that propels more forcefully the unfair trade crusade is the increased criss-crossing of foreign investments which is turning the globalised world into a veritable spider's web. This has increasingly meant that everyone now tends to be in everyone elses backyard, making import competition in one's own market, and export competition in the other's market and in third markets, ever more fierce. In this atmosphere, suspicions of unfair advantage accruing to one's rivals arise readily, fester and then poison the political process that makes trade policy.

5. Yet another aspect of the world economy, the arrival of flexible exchange rates, has added to the problem. Volatility in the exchange rate can wipe you out and your own recourse may be to cry 'foul'. The rival who gains from the changed rate is not going to complain, leaving the floor to those who lose. Dramatic shifts in exchange rates, like the yen-dollar rate before and after the 1985 Plaza Accord, underline the intensity of the problem that can arise. Unless some degree of stability in the structure of exchange rates is achieved by coordination of underlying macro-economic policies, the rise of unfair-trade allegations will be hard to contain.

6. But an important role in making unfair trade concerns potent in politics has been played also by developments in the realm of ideas. In the theoretical modes 
that have recently been analysed, with oligopolistic competition among competing firms from different nations formally modelled, one can demonstrate that the most improbable and negligible-looking form of unfair advantage provided by foreign governments can lead to predatory and large effects on one's industry's competitiveness and survival. The loss of a few high-tech industries to Japan, the visibility of some Japanese governmental support and the assumed presence of invisible support in a myriad of other ways, and the added certitude that those industries have substantial if immeasurable external economies, have combined to make the American scene a potentially fertile ground for such analytical demonstrations to flourish in a symbiotically interacting relationship between the theorists and the interest groups, correspondingly intensifying the obsession with unfair trade.

These converging forces have resulted in:

- A capture, and protectionist misuse, of the traditional unfair-trade mechanisms in regard to important competition, CVD and AD, in both the European Community and the United States, as documented splendidly by Finger and Associates (1992), Hindley (1988), and Messerlin (1989).

- An extension of the unfair-trade concerns to markets for exports, in others' home markets and in third markets.

- An expansion of such concerns to wholly new areas (such as differences in retail distribution systems, saving rates and workers' rights) in regard to fair competition in both imports and exports. The last two developments are more novel and merit further comment.

The notion of unfair trade in one's export markets has led not merely to conventional concerns about subsidies to one's rivals there but to two new twists. First, the question of intra-sectoral reciprocity of trade barriers has become fairly widespread by now, whereas earlier only some 'average' equality (across all imports) of mutual openness of the two countries would have sufficed to meet the criterion. Second, the question of fairness is now considered important enough to justify actions which can only be described as reopening the terms of earlier trade negotiations in view of ex post realities. This is certainly one of the many arguments for seeking unrequited trade concessions from Japan: that the difficulty of penetrating her markets was underestimated and hence the trade concessions given to her were more than those received, and that the situation must be corrected by new concessions by Japan.

These notions are dangerous enough and have driven some of the recent GATT-illegal aggressive unilateralism that will be discussed shortly. ${ }^{3}$ But they are benign compared with the extension of unfair-trade notions to wholly new

\footnotetext{
${ }^{3}$ In principle, 'fair trade' concerns need not lead to aggressive unilateralism. Governments may still stick to multilateral, consensual procedures to pursue their fair trade concerns. Alas, they have increasingly tended not to: such is the power of the notion that others are 'unfair' or venal by one's unilaterally-defined standards.
} 
areas, as in the 1988 Omnibus Trade and Competitiveness Act in the United States and in the Structural Impediments Initiative (SII) with Japan. In both instances, the notion of unreasonable unfair-trade practices has been extended to areas that range over matters as diverse as domestic anti-monopoly policies, retail distribution systems, infrastructure spending, savings rates, workers' rights and so on. The American shopping list in the initial SII talks was reported to have included 240 items.

The problem with trying to include such things, and indeed most policies and institutions, as the natural target for objections that they affect trade and must therefore be scrutinised and changed to suit one's advantage if free trade is to be allowed, is simply that one is opening up a Pandora's Box. ${ }^{4}$ Thus, if Bangladesh has current comparative advantage in textiles, due to lower wages, we no longer need to worry about being scolded as protectionists when we reject imports of Bangladeshi textiles as unfair trade caused by her 'pauper labour'. After all, the low Bangladeshi wages are a result of inadequate population-control policies and of inefficient economic policies that inhibit investment and growth and hence a rise in real wages.

In going down this unwise trade route, we put the world trading system at risk. If everything becomes a question of fair trade, the likely outcome will be to remove the possibility of agreeing to a rule-oriented trading system. 'Managed trade' will then be the outcome, the bureaucrats allocating the trade according to what domestic lobbying pressures and foreign political muscle dictate.

\section{b. Issue of Managed Trade}

Indeed, the question of managed trade has arisen as a threat to the GATT regime, not just because of the outbreak of unfair-trade-mindedness. It has also derived from three other notions: (i) Most trade is managed trade anyway. (ii) Japan, a major player today, is exotic and different; she will not, and cannot, play by rules. And (iii) high-tech industries are so important that they cannot be, or will not be, left to the market place. Each contention is erroneous.

Managed Trade Anyway? That trade occurs frequently by either bypassing or flouting GATT discipline, as with VERs on goods, or outside of its framework, as in agriculture and services, is indeed true. But it is a non-sequitur to conclude that rules do not work and more managed trade must therefore be the way to go. Yet, the glass is half empty and half full. But there is little doubt that it would have been emptier still if the GATT had not provided the overall framework and

\footnotetext{
${ }^{4}$ The policy and theoretical implications of these demands for 'level playing fields' everywhere are explored further in Bhagwati (1991a).
} 
ethos that kept the glass upright instead of falling on its side. Moreover, the issue surely is whether we want to empty the glass further or to fill it up. The Uruguay Round negotiations are properly about filling it further.

Japan-is-different Argument. The 'Japan question' raises different issues, but, for recent critics, leads to a similar conclusion: that managed trade with Japan is either inevitable or desirable. In particular, culturalists have had a field day with their assertion that Japan's cultural uniqueness makes fix-rule trade with her impossible to contemplate and that Japan would in fact prefer managed trade. What is perceived as the 'Japan (trade) problem' has been with us a long time. It has reflected Japan's rapid growth, her import dependence for raw materials and her consequent rapid growth of exports that has been hard to accommodate in the often more sluggish world economy. The giant among Lilliputians has in consequence been repeatedly tied down by quantity restraints on her trade. If the Japanese appear responsive to negotiating on quantities, can it not be that they have learned from their trade history that this is the only way left open to them by their trading partners?

Again, the argument is often made that the Japanese behave differently in competition. They are 'predatory' and hence need to be restrained; our rules are meaningless for such predators. This contention is amusing, and the notion that American and other companies, by contrast, are 'benign' competitors is quite silly. Surely the 'animal spirits' of capitalist entrepreneurs are manifest in the United States and Western Europe as much as in Japan; the jugular is certainly the preferred target of all, although the Japanese may be better at times in getting there. The successful always appear predatory.

High-tech Support? The Japan question, however, feeds an altogether different, more universal, argument for managed trade in the United States. This relates to fear that unless trade restrictions and targets are imposed in high-tech industries, these industries will be lost to countries such as Japan which somehow managed to spawn and support them against the firms in countries that abstain from such support.

Now, while economists have great difficulty in finding externalities in specific industries and are generally inclined to discount claims of their existence in a sufficiently disproportionate degree so as to justify selected support, the opposite is true of politicians. Today, thanks to the scientific revolution that started in informatics and biogenetics, there is virtually no politician in any major developed country who does not feel that high-tech industries must be attracted and supported for their manifest externalities and, in non-economic terms, for their identification with modernisation in view of their state-of-the-arts and atthe-frontier status.

Given these perceptions, which then becomes realities that economists must work with, it is evident that a rules-oriented free trade system in high-tech industries will not be workable unless 
- either there is a multilateral mechanism for bringing up front the various differing ways in which different governments are alleged to be biasing the outcomes in their favour, so that the 'net balance' of such artificial advantages among the different rivals is sorted out and then eliminated;

- or one goes yet further and manages essentially to get an acceptable degree of harmonisation (that then irons out the differences) by adherence to a code of do's and don'ts.

The latter may not be possible if governments have definite and differing preferences for certain policies. The former surely is possible and would enable the Japanese to point to such artificial US advantages that may stem from higher defence expenditures and support for science through the National Science Foundation when the Americans complain about the Japanese Government's guidance and support to pooled research, etc. The multilateral format would ensure that the finger-pointing would be fair and balanced, where appropriate, without the advantage of the thicker finger in bilateral one-on-one confrontations.

This solution where the trade issue would be managed by institutional innovation so as to maintain the fix-rule regime in high-tech industries was proposed in Bhagwati (1988). The idea of a code for high-tech has since been taken up also by Ostry (1990) in a study of trade and innovation policies in the triad constituted by the United States, the European Community and Japan. It is important to emphasise, however, that these proposals are for 'trade management', not for 'managed trade'. A fix-rule regime is consistent with the former: in fact, the Tokyo Round codes, negotiations on trade-barrier reductions, the establishment of new disciplines, the enforcement of one's trade rights and assurance of fulfilment of one's trade obligations are all part of 'trade management' that would support and sustain the fix-rule regime. 'Managed trade', on the other hand, is the antithesis of the fix-rule regime. This is emphasised simply because, with the free entry of amateurs into this politicallyrewarding field, the two wholly opposed concepts are increasingly confused and used interchangeably.

\section{c. Aggressive Unilateralism}

The concerns over unfair trade have created yet another hazard for the fix-rule GATT system in the recent use of aggressive unilateralism by the United States to impose on others its unilaterally-defined views of unfair trade practices.

I refer here, of course, to the use of the Section 301 and super 301 provisions of American trade legislation, as updated in the 1988 Act, to demand negotiations from specific countries on 'priority' practices that the United States find unacceptable, regardless of whether they are proscribed by the GATT or another treaty, and to seek their abolition on a tight time schedule set by the 
United States, using tariff retaliation by the United States if necessary. What is the problem with this policy? ${ }^{5}$

Question of GATT-illegality. At the outset, it must be understood that the GATT has the force of a treaty for the United States. Now, when the United States retaliates, as it has already in some Section 301 actions imposing tariffs against particular goods of a targeted country, the GATT-illegality is at several levels. The discriminatory nature of such tariffs violates Article I which imposes the MFN obligation. Also, since the tariff is in practice likely to be bound at a lower level than the retaliatory tariff, this will generally be in violation of Article II as well.

Why Does GATT-illegality Matter? Prima facie, honouring a treaty commitment is to reaffirm one's respect for orderly procedures and the rule of law in dealing with other nation states. But does vigilantism have a place when the sheriff is asleep in the saloon? Or, to rise to a higher principle, is there not a case for 'justified disobedience', as Hudec (1990) has put it, when the law is not working as it should? In either case, a doctrine of 'creative illegality' is being invoked: a breach of law to improve the law is being claimed.

The problem with this line of defence by the United States of GATT-illegality (to improve an ineffective GATT) is that almost no one else in the trading system quite accepts this justification. Indeed, as Hudec has noted, the United States' own record of acting within the rules to respect others' GATT-defined rights has not been exemplary.

There is also the problem that means may affect ends. It is not likely that a declared willingness to break GATT commitments, and actual breach thereof, may spread cynicism towards such commitments by others rather than adherence to them in the future? I would even suggest that it undermines the credibility of the commitments accepted by nations that take the law thus into their own hands. Thus, in the recent Uruguay Round negotiations, there has been substantial progress on the possible dismantling of the MFA in textiles. The United States has made commitments in its offer, which however, mostly come at the end of the 10-year period which is agreed upon. Some of the key developing countries, having seen the recent tendency in the US Congress to have its way regardless of GATT obligations and to use American economic muscle to pursue unilaterally-defined agendas, are frankly sceptical whether, when the time comes, the United States will simply dishonour its commitments and say: sorry, we cannot deliver.

\footnotetext{
${ }^{5}$ One aspect of Section 301 actions and intentions is also the extraction from others of unrequited concessions, in contrast to the mutual concessions that characterise the GATT negotiations. It is also possible to argue that 301 may be used for 'altruistic' reasons such as moving everyone towards a better trading regime, as in the Uruguay Round negotiations, and is not necessarily a tool for improving only US welfare. These alternative 'rationales' and objectives behind 301 are explored in depth in the present author's contribution to Bhagwati and Patrick (1990).
} 
Trade Diversion. Let us now turn to other dangers inherent in this form of unilateral extraction of trade concessions from others. In particular, since it reflects clout and concentrated pressure, there is a strong likelihood that the targets of Section 301 actions will satisfy American demands by diverting trade from other countries (with small political clout) to the United States, satisfying the strong at the expense of the weak. Admittedly, USTR Ambassador Carla Hills repeatedly stresses that USTR will ensure that markets are opened under Section 301 in a non-discriminatory fashion. But ex ante intentions can diverge from ex post outcomes. The countries targeted for action know that the American pressures are more likely to ease if the United States gets a good share than if it does not.

Atmospherics. There is also the possibility that the use of muscle to impose one's own views and to extract one-way trade concessions will poison the ethos of fairness in trade relations without which open markets are hard to sustain.

A Benign Dictator? Even if one makes the implausible assumption that Section 301 is used only for 'altruistic' reasons (such as using muscle to make progress in the Uruguay Round negotiations), the notion that the United States should serve as a benign dictator, laying down its own definition of a desirable trading regime instead of making (admittedly slower) progress by persuasion and mutual concession, is hard to accept. Institutions cannot be built on notions of benign dictatorship: this is a lesson that the functioning of democracy in the United States itself, with all the slowness and 'inefficiencies' that practitioners of realpolitik complain about, amply teaches us all.

We must also confront the fact that trade policy is rarely made in pluralistic democracies by dictators with monolithic objective functions. Instead, it reflects the resolution of sectional interests in the political domain. There is no necessary correspondence, therefore, between the triumphant sectoral interests and the national interest and, most important, the international or cosmopolitan interest that must define the world trading regime.

The instrument of aggressive unilateralism therefore has important drawbacks and somehow the supporters of a rules-based multilateral trading system will have to find a way of cutting it down to size through an agreement proscribing the use of such instruments. In retrospect, however, one can compliment Ambassador Hills on having navigated, with minimal damage to date, in the stormy waters that the US Congress has created with its ill-considered legislation.

\section{d. Regionalism}

The obsession with unfair trade, the flirtation with managed trade and aggressive unilateralism: these threats to the fix-rule, multilateral GATT system are real and, in my view, few knowledgeable scholars will disagree on the issues 
they raise. But an altogether different, and debatable, type of threat to the GATT system is posed by the recent growth of regionalism a la Article XXIV of the GATT. ${ }^{6}$ The nature of the threat must be clearly understood therefore, and ways of containing it must be found.

1. Free trade areas (FTAs) and customs unions (CUs) are GATT-compatible thanks to Article XXIV. The reasoning underlying the inclusion of Article XXIV in the GATT must have reflected three rather different rationales. First, full integration on trade, i.e., going all the way down to freedom of trade flows among any sub-set of GATT members, would have to be allowed since it created an important element of single-nation characteristics among these nations, and implied that the resulting quasi-national status following from such integration in trade legitimated the exception to MFN obligation towards other GATT members. Second, the very fact that the exception would be permitted only for the extremely difficult case where all trade barriers would need to come down, precluded the possibility that all kinds of preferential arrangements would break out, returning the world to the fragmented, discriminatory bilateralism of the 1930s. Third, one could think of Article XXIV also as permitting a supplemental, practical route to the universal free trade that the GATT might be said to favour implicitly as the ultimate goal, the general negotiations during the many rounds leading to a dismantling of trade barriers on a GATT-wide basis, while deeper integration would be achieved simultaneously within those areas where the politics permitted faster movement to free trade under a strategy of full and time-bound pre-commitment.

2. It is fair, therefore, to say that regional integration was not thought of, either at the GATT's creation or subsequently, as necessarily antithetical to the GATT. The United States, however, was certainly not an enthusiastic convert to Article XXIV, having perceived itself as a victim of Imperial Preference and thus having long been suspicious of discriminatory trade arrangements. But, while it restrained itself from resorting to Article XXIV, the formation of the European Common Market in 1958 marked a partial watershed. The United States put its shoulder to the wheel and saw the Common Market through, negotiating around the different hoops of Article XXIV, emasculating the Article somewhat so as to seek GATT approval of an imperfect union, all in the cause of what it saw as a politically beneficial union of the original Six that formed the Common Market.

3. This in fact accounts for why, despite the enthusiasm in the 1970s of Harry Johnson and others for a North Atlantic Free Trade Area, and even a Pacific Free Trade Area, nothing came of it; the United States remained indifferent to such notions.

\footnotetext{
' Article XXIV permits discrimination against GATT members, denying them MFN rights, if a sub-set of members forms a free trade area or a customs union.
} 
If the US-centered proposals for FTAs were largely patterned on the Common Market's less-demanding neighbour, the European Free Trade Association (EFTA), there was an outbreak of such proposals in the developing countries as well. While stimulated by the European examples, they were motivated by an altogether different economic rationale. This was that, given any targeted level of import-substituting industrialisation, the developing countries, with their small markets, could reduce the cost of this industrialisation by exploiting economies of scale through preferential opening of markets with one another. ${ }^{7}$ By the end of the 1960s, however, the attempts at forming regional FTAs and CUs along these lines had also collapsed. The problem was that, rather than use trade liberalisation and hence prices to guide industry allocation, the developing countries attempting such unions sought to allocate industries by command and then tie trade to such allocations, putting the cart before the horse and killing the forward motion. ${ }^{8}$

Thus, while the world was indeed filled, in the 1960s, with all variety of proposals for regional blocs, regionalism had virtually died by the end of the decade - except for the original Common Market and EFTA.

4. The revival of the Article XXIV variety of regionalism today, in this historical perspective, raises the questions: will regionalism today die as the earlier, equally dramatic one did; and why is regionalism feared today as a threat to the GATT? That the current rise of regionalism is likely to endure and gain in strength seems probable: history is unlikely therefore to repeat itself. There are several reasons for this.

First, the conversion of the United States, hitherto an abstaining party, to Article XXIV with its FTAs with Israel and, more importantly, with Canada represents a change of considerable importance. The United States is widely perceived as a major player, and its changed attitude on Article XXIV is a major event that shifts the balance of forces towards regionalism, as compared with the situation in the $1960 \mathrm{~s}$.

Second, Europe 1992 and the impending integration of Eastern Europe into the European Community have reinforced - in the way the formation of the Common Market in 1959 did with many then - those in North America who feel that a countervailing bloc must be formed there as well.

Third, there are strong non-economic, political and cultural factors also driving Mexico towards a FTA with her northern neighbour. The Hispanic destiny that many in America fear from illegal immigration and integration with Mexico has its flip side in the American destiny that Mexico's reforming elite, trained in the top United States universities, hopes for.

\footnotetext{
${ }^{7}$ This rationale was developed by many writers, including Cooper and Massell (1965), Johnson (1965), and the present author - Bhagwati (1968) - at the time.

${ }^{8}$ A splendid analysis of this failure is provided by Dell (1966).
} 
Fourth, the offer by President Bush to get more nations from South America to join the United States in a FTA, is reflective of the compulsions that the debt crisis imposes on American policy to respond in a regional framework to ensure that this crisis remains manageable and does not engulf the United States whose banks are principally endangered by it.

Finally, the conjunction of the two dramatic events, Europe 1992 and the United States-Canada FTA and impending North American FTA, even though fortuitous and prompted by different motivations and historical circumstances, has created a sense elsewhere that regionalism is the order of the day and that others must follow suit.

5. But if regionalism is likely to endure this time, the perception that it will undermine the GATT is also different from the perception in the 1960s that it was generally compatible with, rather than antithetical to, the GATT.

This fearful perception arises from two different sources. There is the fear that the preoccupation with Europe 1992, with the extension of the United States-Canada FTA to include Mexico, and their possible further expansions, will take the attention of the major players, the United States and the European Community, away from the Uruguay Round and its critical task of remaking the GATT. But there is little evidence that the feared neglect of the Uruguay Round negotiations has occurred enough to put the whole endeavour at risk.

There is more substance however, to the fear that the repeated American 'strategic' argument that regionalism (and agreements among like-minded nations) would be America's new weapon if the GATT were not amended and bent to American demands for reconstitution and reform, combined with actual resort to regional arrangements, will produce the negative perception that regionalism is antithetical to the GATT and that, if Article XXIV-sanctioned FTAs proliferate, this is somehow the nemesis of the GATT. This false antithesis certainly prompted Thurow's earlier mentioned error of judgment in calling our attention to a live corpse.

Nonetheless, since the impression has spread that the regional FTAs and CUs are fragmenting the world economy, instead of progressively unifying it along with the multilateral initiatives, and that the GATT is therefore being sidelined, it is necessary that the older, and wider, perspective be restored by confidencebuilding measures and by revisions in Article XXIV and other GATT Articles. Among them might be the following:

- A forceful statement from the major players (through G-5, G-7, and other institutions) that regionalism and the GATT are not incompatible; and that the GATT remains the central institution overseeing issues of world trade policy, despite regional blocs.

- Insistence at the GATT on a strict interpretation of Article XXIV in regard to all newly-emerging and prospective FTAs so that less demanding 
preferential and discriminatory arrangements do not multiply in the present pro-regionalism climate.

As for the revisions to GATT Articles, the following are important:

- Article XXIV needs to be re-examined to ensure its true consonance with GATT's general objectives. This requires that the immediate trade diversion be minimised and that the trade blocs continue to coalesce towards worldwide free trade instead of fragmenting the world economy.

1. I have suggested (Bhagwati, 1991a) that one way to reduce trade diversion would be to rule out FTAs and to admit only CUs (which have a common external tariff). Since the United States is the principal source and partner of new preferential arrangements, and since it is basically a low-tariff country, this would imply that any proposed CU with, say Brazil, would mean that Brazil's external tariffs would have to be brought down to US levels. A more compelling rule, on the other hand, would simply be to insist also that, on any commodity, the lowest of the tariffs existing in any member of the $\mathrm{CU}$ prior to the $\mathrm{CU}$, would have to be adopted as part of the CU's common external tariff.

2. Also, since we would want the CU's to move onto further expansion towards worldwide free trade, a formal inclusion in Article XXIV of the obligation on the part of any existing CUs to be open to new membership from GATT contracting parties would also be a step in the right direction.

- Whereas the suggestion above about CUs being preferable to FTAs to prevent trade diversion relates essentially to preferential tariffs as the cause of potential trade diversion, it is necessary to recognise that today the trade protection comes instead in the form of mainly VERs (voluntary export restraints), AD (anti-dumping) actions and CVD (countervailing duty) measures. These instruments are selective and they are elastic: they can result in varying levels of protection.

The analysis of trade diversion in preferential trading arrangements then cannot proceed without recognising that, given these selective measures which can be targeted at nonmembers, trade-creating situations can be transformed endogenously into trade diversion. Thus, imagine a trade-creating impulse in a US-Mexico FTA. Assume that the United States crowds Mexico in an industry where Mexico is the least efficient and Taiwan the most efficient supplier. If trade barriers were conventional and given, there would be trade creation. But now Mexicans have the option of protecting their industry and accepting US exports at the expense of Taiwan exports by starting up $\mathrm{AD}$ actions against Taiwan. Again, if Mexico crowds a US industry, then the United States (being more powerful) can even impose VERs on Taiwan. In GATT cases, trade creation would have been replaced by trade diversion via the use of elastic and selectively targeted trade barriers against efficient nonmembers of the FTA. I would guess that a sizeable fraction of the AD actions by the EC against the Far East, documented fully by Hindley (1988) and Messerlin (1989), are a response 
to intensification of internal competition following the Common Market and hence fits into my model.

If so, evidently we need to rein in these selective instruments if we are going to go the regional route; else trade diversion will break out. This means that we need greater discipline on the use of these instruments at the GATT. Article VI on anti-dumping must be tightened to exclude the capture by protectionists that is notoriously evident today. Equally, VERs should be proscribed and the discipline of Article XIX on safeguards protection, which mandates nondiscriminatory protection, must be enforced. In short, if we go the regional route, the GATT must be strengthened in these ways, not weakened! Those who think of regionalism and the GATT as alternatives have therefore not thought the matter through at a deeper level.

\section{REFERENCES}

Bhagwati, J. (1968), 'Trade Liberalization Among LDCs, Trade Theory, and GATT Rules,' in J. N. Wolfe (ed.), Value, Capital, and Grow'th: Essays in Honour of Sir John Hicks (Edinburgh: Edinburgh University Press).

Bhagwati, J. (1988), Protectionism (Cambridge, MA: MIT Press).

Bhagwati, J. (1991a), 'Fair Trade, Reciprocity, and Harmonization: The Novel Challenge to the Theory and Policy of Free Trade,' in A.V. Deardorff and R.M. Stern (eds.), Analytical and Negotiating Issues in the Global Trading System (Ann Arbor: University of Michigan Press, forthcoming).

Bhagwati, J. (1991b), The World Trading System at Risk (Princeton: Princeton University Press).

Bhagwati, J. and D. Irwin (1987), 'The Return of the Reciprocitarians: US Trade Policy Today,' The World Economy, 10, 109-30.

Bhagwati, J. and H. Patrick (eds.) (1990), Aggressive Unilateralism (Ann Arbor: University of Michigan Press).

Cooper, C.F. and B.F. Massell (1965), 'Towards a General Theory of Customs Unions for Developing Countries,' Journal of Political Economy, 73, 461-76.

Dell, S. (1966), 'The Viability of Small Countries' in S. Robock and L. Solomon (eds.) International Development (New York: Oceana Publications).

Finger, J.M. and Associates (1992), If at First You Dont Succeed: How Antidumping Works and Who Gets Hurt, forthcoming.

Hindley, B. (1988), 'Dumping and the Far East Trade of the European Community,' The World Economy 11, 445-64.

Hudec, R. (1990), 'Section 301: Beyond Good and Evil,' in J. Bhagwati and H. Patrick (eds.).

Johnson, H.G. (1965), 'An Economic Theory of Protectionism, Tariff Bargaining and the Formation of Customs Unions,' Journal of Political Economy, 73, 256-83.

Messerlin, P.A. (1989), 'The EC Anti-dumping Regulations: A First Economic Appraisal 1980 85,' Weltwirtschaftliches Archiv, 125, 563-87.

Ostry, S. (1990), Governments and Corporations in a Shrinking World (New York: Council on Foreign Relations). 